\title{
Can we effectively stop the expansion of trees on wetlands? Results of a birch removal experiment
}

\author{
Andrzej K. Kamocki • Aleksander Kołos · Piotr Banaszuk
}

Received: 28 February 2016/Accepted: 22 November 2016/Published online: 30 November 2016

(C) The Author(s) 2016. This article is published with open access at Springerlink.com

\begin{abstract}
The main aim of this study was to determine the effectiveness of removing invasive downy birch in non-forest peatland applying a single cut. We tested whether the removal of birch was positively related to the height of cutting, season of the year and age of the trees. Our study showed that birch trees cut at the higher tested height exhibited a lower survival rate than those cut below or just above the ground level. Furthermore, the winter cut produced more non-sprouting stumps than those recorded after the cut performed in autumn. In our opinion, winter cutting at breast height is the best management strategy for downy birch control. However, we suppose that the effective elimination of birch by applying a single cut is not possible, and the treatment should be repeated in subsequent years or boosted by additional treatments.
\end{abstract}

Keywords Betula sp. · Secondary succession · Sprouting · Tree removal · Vegetation management

A. K. Kamocki ( $\bowtie) \cdot$ A. Kołos · P. Banaszuk Department of Environmental Protection and Management, Białystok University of Technology, Wiejska 45A, 15-351 Białystok, Poland

e-mail: a.kamocki@pb.edu.pl

\section{Introduction}

Encroachment of woody plants and shrubs in open wetlands and grasslands is a worldwide concern (Bart et al. 2015). Formerly characterized by lowintensive management systems, these ecosystems have undergone a major decline in area in recent decades (COM 2015). The open wetlands are of special concern. While they only comprise a small part of wetlands area, open wetlands are very important for a wide variety of species (EEA 2015). The succession and progression of shrubs and trees was shown to be a direct threat to many shade-intolerant, low herbaceous species that are unsuccessful in competing for resources. Thus, this phenomenon is regarded as one of the drivers of biodiversity loss at ecosystem and landscape scales (Warren et al. 2004, 2007; EEA 2015). This problem is crucial in wetlands where vegetation composition results from long-lasting low-input agricultural use (Kotowski and Piórkowski 2005). Cessation of this traditional land use initiates a secondary succession, which within a few decades results in the progressive decline of less competitive helophytes, especially those that occur at their geographic range limit (Kołos et al. 2015). The secondary succession of trees and shrubs will also be a main challenge for controlling mire hydrology in the near future. The results of preliminary research by Grygoruk et al. (2014) confirmed that tree isles in mire habitats cause a higher degree of water loss through 
evapotranspiration relative to that of continuous expanding forest.

The shift of peatland vegetation towards treedominated ecosystems may likely be accelerated by anthropogenic disturbances (i.e., drainage; Tousignant et al. 2010), climate change (i.e., future warming; Heijmans et al. 2013), external eutrophication (i.e., atmospheric deposition; Riemersma et al. 2006; Jickells 2005; Smith et al. 1999), and abiotic variables (i.e., water fluctuations, N:P ratio; Økland et al. 2001; Jabłońska et al. 2014). Thus, protecting open wetland ecosystems is a priority of nature conservation policy. In the European Union and in other countries, several conservation programs are available to assist landowners in developing wetland management on their property (Baylis et al. 2008; Claassen et al. 2008). Although management and restoration practices are routinely performed, we still lack systematic, evidence-based assessments of their effectiveness (Meli et al. 2014), e.g., in the control of trees encroachment. Some field results suggest that the most effective method for eliminating expanding trees is repetitive mechanical removal coupled with the application of herbicides (Klimkowska et al. 2010; Brisson et al. 2006). Because herbicide treatments may produce unknown cumulative impacts on the environment (Sura et al. 2012), their application (as well as burning) is illegal in protected areas in many countries, including in Poland. Presently, repetitive mowing and/or tree and shrub cutting are acknowledged as the only acceptable and potentially effective tool for vegetation management (Middleton et al. 2006; Kołos and Banaszuk 2013).

Birch a very dynamical pioneer species in peatland is likely to respond well to cutting and pollarding, and the full crown can possibly be removed. Old trees have been documented to die after removal of the crown (Read 2000). The cut disrupts the hydraulic architecture and continuum of the food- and water-conducting tissues ("the soil-plant continuum"). Consequently, it results in a great flow of sap and considerable loss of carbohydrates that serve as the primary energy reserve of trees. Resprouting after severe damage and loss of a majority of aboveground biomass requires resources to support the development of new resprouts (Bond and Midgley 2001; Zhu et al. 2012). Severe depletion of carbohydrate reserves can affect the regeneration capacity of the tree after damage (Luostarinen and Kauppi 2005) and can lead to its death. Wounds also expose the tree to pathogens (e.g., fungi) that may infect and cause decay of the wood (Delvaux 2009). There is evidence that stump survival as well as sprouting ability is related to felling time and residual stump height (Ferm and Kauppi 1990; Hytönen 1994; Jobidon 1997).

Repeated yearly cutting increases the mortality of trees and reduces sprouting. However, experience and observations gained in managed wetlands have shown that these simple and obvious measures are sometimes either ineffective or, contrary to all expectations, even triggering unwanted successional changes. Moreover, the major drawbacks of repeated management include the high cost of additional treatments and possibility of enhanced environmental stress or disturbances (Banaszuk et al. 2016). The main aim of this study was to determine the effectiveness of removing invasive downy birch in an unwooded peatland by applying a single cut. The principal issues pertained to the effect of both the method and timing of the cutting on the sprouting ability and survival of downy birch Betula pubescens stumps. The study addressed the following questions: (i) "does applying a single cut enable the restoration and maintenance of nonforested mires colonized by downy birch?" and (ii) "how does cutting season and cutting height affect the sprouting ability of Betula?"

\section{Materials and methods}

Study site

This study was conducted in the nature reserve "Stare Biele Mire" located in the Knyszyńska Forest, northeast Poland $\left(53^{\circ} 14^{\prime} 36^{\prime \prime} \mathrm{N} ; 23^{\circ} 31^{\prime} 35^{\prime \prime} \mathrm{E}\right)$. The mire has an area of 300 ha and was developed in a melt-out depression surrounded by kame hills. The isolated basin is filled with poorly decomposed (fibric and hemic) Carex-Bryales peat of an average depth of $1.7 \mathrm{~m}$, which is underlain by lacustrine deposits (average depth of $1.3 \mathrm{~m}$; Żurek 2000). The mire has a long history of agricultural use. Beginning eighteenth century, it was mown annually for fodder production. By the early 1970s, mowing had ceased, and secondary plant succession had started, which has lead to massive encroachment of downy and silver birch (Betula pendula), pine (Pinus sylvestris), spruce 
(Picea abies), grey willow (Salix cinerea) and bay willow (Salix pentandra), which account for up to 50-70\% coverage (Fig. 1). Semi-natural sedge-moss communities dominated by Carex elata and Carex appropinquata only remained in the middle and eastern part of the peatland. Within the Carex community, a few individuals of Salix lapponum survived, which is one of the rarest glacial relicts of Polish flora, as well as other rare and endangered species of fauna and flora (Kołos et al. 2015).

The climate is temperate and has a distinctly marked continental and a lesser boreal influence. The mean air temperature is $7.0^{\circ} \mathrm{C}$, the monthly average temperature ranges from $-3.9{ }^{\circ} \mathrm{C}$ in January to $17.8^{\circ} \mathrm{C}$ in July, and the average rainfall is $585 \mathrm{~mm} \mathrm{year}^{-1}$ (1951-2013), of which 60-80\% falls between April and September. Permanent snow cover occurs over 70-80 days on average every year between late December and early March. The maximum snow depth reaches $80 \mathrm{~cm}$ in some years. The growing season has mean daily air temperatures $>+5{ }^{\circ} \mathrm{C}$, begins on approximately 5 April and lasts 180-200 days.

The experimental period 2010-2013 experienced high precipitation. The wettest year was 2010, when the sum of the precipitation for the growing season alone exceeded $560 \mathrm{~mm}$. Groundwater levels during the experiment showed the highest frequency around the ground surface, with a shallow flood reaching approximately $12 \mathrm{~cm}$ (water level was measured using e+ water L 200 data loggers by Eijkelkamp Agrisearch Equipment, Giesbeek, the Netherlands, in a piezometer close to the experimental plots). In the 4 years study period the mire was flooded every year. Average flood duration was 132 days and usually occurred in the period from the beginning of March

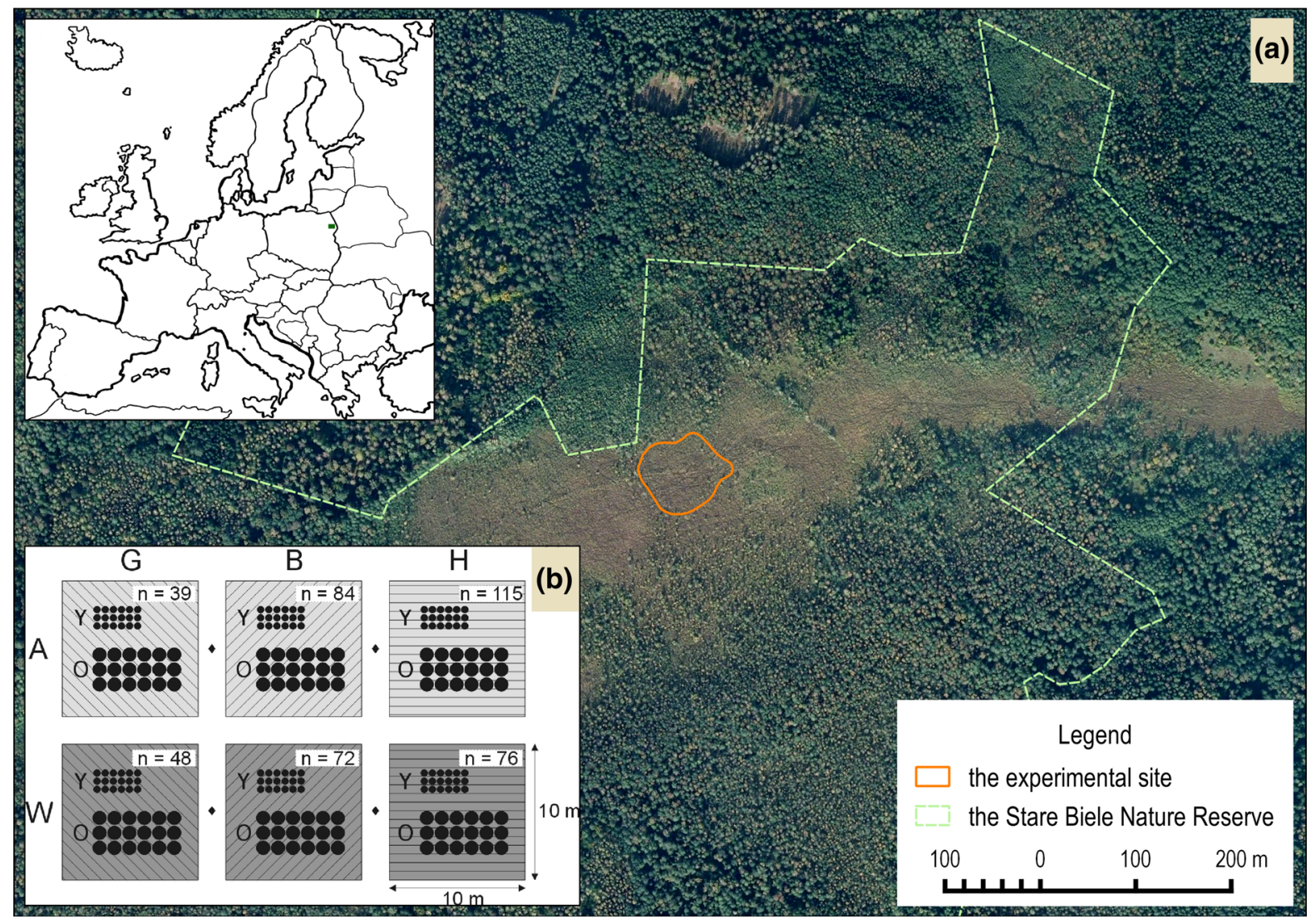

Fig. 1 Stare Biele Mire study site (a) and sampling scheme (b). Total number of treated individuals is shown in the top right corner of each plot. A cut in autumn season, $W$ cut in winter season, $Y$ young trees with the trunk diameter $<12 \mathrm{~cm}, O$ older trees with a diameter $>12 \mathrm{~cm}, G$ cutting below the ground surface, $B$ cutting 5-10 cm above the ground; $H$ cutting $120 \mathrm{~cm}$ above the ground 
until June. The minimum recorded water table was $-17 \mathrm{~cm}$; however, temporary shortages in soil moisture were efficiently replenished by the frequent rainfall.

The shallow groundwater/pore water from the depth of the rooting zone was sub-neutral with an average $\mathrm{pH}$ of $6.7 \pm 0.27$ and exhibited a rather low mean electrical conductivity (EC) of $258 \pm 29.2$ $\mu \mathrm{S} \mathrm{cm}^{-1}$ (measurements were repeated once a month; $\mathrm{n}=18$; Hach Lange HQ40D). The groundwater of this oligotrophic mire had a low $\mathrm{N}-\mathrm{NO}_{3}$ concentrations (mean $0.03 \pm 0.01 \mathrm{mg} \mathrm{L}^{-1}$ ). The concentration of $\mathrm{N}$ $\mathrm{NH}_{4}^{+}$was $0.67 \pm 0.41 \mathrm{mg} \mathrm{L}{ }^{-1}$, and $\mathrm{P}_{-} \mathrm{PO}_{4}{ }^{3-}$ was $0.04 \pm 0.02 \mathrm{mg} \mathrm{L}^{-1}$. Relatively high concentrations of $\mathrm{Ca}^{2+}$ (mean $63.1 \pm 16.1 \mathrm{mg} \mathrm{L}^{-1}$ ) and $\mathrm{Mg}^{2+}$ (mean $10.5 \pm 1.0 \mathrm{mg} \mathrm{L}^{-1}$ ) confirm that the water feeding the wetland has a groundwater origin.

\section{Experiment}

Our project was situated in the nature reserve; therefore, a randomized experiment faced some constraints for legal and ethical reasons. To mitigate any potential negative impact on the fragile peat soil and vegetation, we had to restrict the spatial extent of the field work and management practices. Within the mire, we identified relatively uniform fragments characterized by similar peat depth, hydrology and soil properties. The area had an almost even-aged stand of Betula in which the difference in the age between the oldest and youngest trees did not exceed 10-20 years. The stand density in the plots varied between 39 and 115 individuals $/ 100 \mathrm{~m}^{2}$.

Within this fragment of peatland, we randomly selected 6 plots $(10 \mathrm{~m} \times 10 \mathrm{~m})$. The tree cutting was applied to all individuals and was performed in two different periods: at the end of the growing season in the middle of October 2011 [Autumn (A)] and in February 2012 [Winter (W)] using three methods: cutting below the ground (peat) surface $(\mathrm{G})$, cutting $5-10 \mathrm{~cm}$ above the ground at the base of the trunk (B) and cutting the trunks at breast height $(120 \mathrm{~cm} ; \mathrm{H})$. Thus, six different treatment combinations were obtained: AG, AB, AH, WG, WB and WH. For each plot, we randomly assigned the treatment type that each plot was to receive. Before the treatment, the perimeter of tree trunks was measured at breast height. The measurements were noted on a plastic plate, which was then stuck into peat nearby the trunk. The cut trees were aged from several to more than a dozen years old, and they were up to $6 \mathrm{~m}$ tall. Age was presented in a simplified dichotomous scale: young trees with a perimeter of trunks $<\sim 12 \mathrm{~cm}(\sim 4 \mathrm{~cm}$ in diameter; Y) and older trees with perimeter $>12 \mathrm{~cm}$ (O). A relative homogeneity of the habitat allowed us to suppose that the differences in the tree perimeter reflected fairly accurately the difference in the age and thus might be a good proxy of tree age. The stand density and the number of trees in the analyzed plots were different from each other; therefore, to consider the individuals within every single plot, we sampled equal-size groups ( $\mathrm{n}=18$ individuals) that represented the specific combinations of factors: young trees cut below ground level in October (YBA), young trees cut below ground level in February (YBW), etc.-in sum, $\mathrm{n}=12$ groups. All trunks and branches were removed from the site. We did not test the effectiveness of Betula removal in the summer halfyear because, in protected areas, all management measures are restricted during the bird-breeding season, which extends between April and August. After applying the appropriate treatment independently to each plot, we made no further manipulations until mid-August of next year. The response of downy birch to cutting was monitored during two consecutive seasons in 2012 and 2013. The proportion of dead, damaged or diseased trees along with decreased production of sprouts by the stumps and roots of cut trees were accepted as indicators of successful tree removal. In addition, the post-treatment damages of the stems (e.g., infection by fungi) were also monitored.

\section{Data analysis}

The experimental units were the individual trees, to which treatment was assigned. The treatment's impact on the mortality of Betula was tested using a multifactor analysis of variance (MANOVA). We tested whether successful eradication (measured as a decrease of sprouts produced by the treated tree) was positively related to the method of cutting $(\mathrm{G}, \mathrm{B}$ and $\mathrm{H}$ ), the season when the treatment was performed (A and $\mathrm{W}$ ) and the age of the trees. The data were used to test the null hypothesis that differences would not be found in the mean number of sprouts across the different treatment groups. In all cases, the statistical 
design was balanced with type III sum of squares (SS). The dependent variable was $\log 10$ transformed. Differences in the sprouting ability of Betula among treatments were analyzed using a non-parametric Kruskal-Wallis test. A Chi squared test was performed to determine whether significant differences occurred among the proportions of dead trees within the treatment groups. An analysis of means (ANOM) was used to determine the proportions that were significantly different compared to the overall average. All analyses were performed using Statgraphics XVI Centurion software (Statpoint Technologies, Inc.).

\section{Results}

Effect of cutting season and height on sprout production and birch survival

In the first year after the treatment (2012), we recorded significant effects of the season when a treatment was
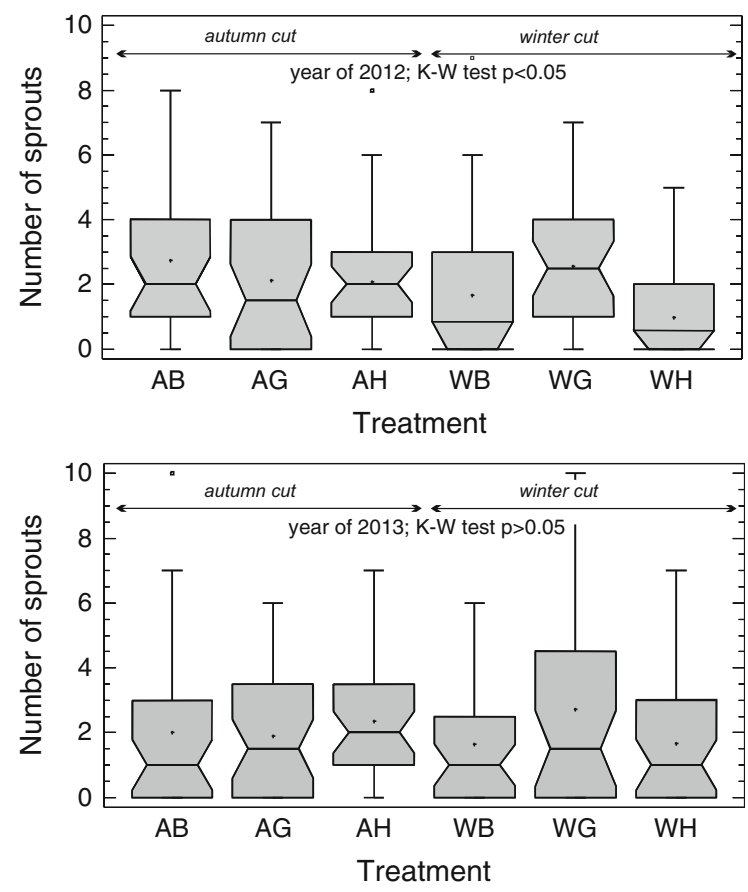

Fig. 2 Sprout production per stump after applying different methods of birch removal, as recorded in 2012 (upper panel) and 2013 (lower panel). $G$ cutting below the ground surface, $B$ cutting $5-10 \mathrm{~cm}$ above the ground, $H$ cutting $120 \mathrm{~cm}$ above the ground, $A$ autumn, $W$ winter applied on the sprouting ability of birch $(\mathrm{p}<0.05$; Kruskal-Wallis test; Fig. 2). The median number of sprouts per stump after the winter cut (1.0) was significantly lower than those recorded after the cut performed in autumn (2.0). The most effective method was winter cutting at breast height $(\mathrm{WH}$; the median sprouting per trunk $=1$ ); the least effective was winter cutting below the ground surface (WG; median $=2$ ).

Measurements repeated in the subsequent year (2013) showed that median sprouting per trunk was slightly lower (1.5) than in 2012. However, the observed difference was not statistically significant. There were no significant influences of cutting method or season on the number of sprouts.

The MANOVA results revealed that the age of the trees under treatment was the only factor that had a significant effect $(\mathrm{p}<0.05)$ on the condition of the cut birch with young trees producing less sprouts (Fig. 3). A comparison between the variability among treatment effects and that of the residuals indicated that only this factor showed a difference of a greater magnitude than could be accounted by experimental error alone. A height of tree cut appeared to be marginally significant at $\mathrm{p}<0.10$ ("treatment" in Fig. 3).

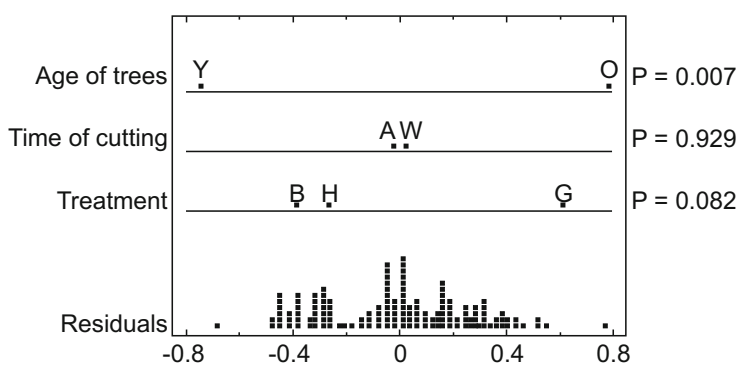

Fig. 3 A graphical ANOVA plot comparing the variability among treatment effects on the number of sprouts per one stump to that of the residuals. Each factor was scaled so that the "effect" of a factor equaled the difference between the least squares mean for a factor level and estimated grand mean. The natural variance of the points in the diagram is comparable to that of the residuals, which are displayed at the bottom of the plot. The p-values for the main effects are displayed along the right-hand side of the plot. $Y$ young trees with the trunk diameter $<12 \mathrm{~cm}, O$ older trees with a diameter $>12 \mathrm{~cm}$, $G$ cutting below the ground surface, $B$ cutting $5-10 \mathrm{~cm}$ above the ground, $H$ cutting $120 \mathrm{~cm}$ above the ground, $A$ autumn cutting, and $W$ winter cutting 
Effectiveness of the cut treatment estimated according to the number of dead trees

In the first year (2012) after performing the cut, the proportion of dead (non-sprouting) trees varied according to the method and season of treatment. The most successful (Chi square test, $\mathrm{p}<0.05$ ) combinations were the winter cuts performed at the base of the trunk (WB) and at breast height (WH). In both cases, the proportion of dead trees was slightly higher than 50\%. Cutting below the peat surface (WG) resulted in over $80 \%$ tree survival. The ANOM showed that these proportions were significantly different $(\mathrm{p}<0.10)$ than the overall average from all of the experimental plots (Fig. 4). Birch tree removal in autumn was less successful than that performed in winter. Trees cut below the ground surface (AG) provided a $40 \%$ success rate, cut $\mathrm{AB}$ eliminated $\sim 13 \%$, whereas cut $\mathrm{AH}$ eliminated $16 \%$ of the trees.

Counting repeated in the second year after treatment (2013) revealed the greatest tree mortality in the plot with autumn cuts below the ground surface (AG), which gave $46 \%$ of dead trees (Fig. 5). The worst results were observed with autumnal cuts at breast height $(\mathrm{AH})$, which produced a proportion of dead trees of $17 \%$. Surprisingly, the proportion of stumps without sprouts in the plots with the highest success in 2012 (WB and WH) decreased in the next year. The same tendency was also observed in other plots $(\mathrm{AB}$, $\mathrm{AG}$, and $\mathrm{WG}$ ), where the rate of success decreased to $30-40 \%$.

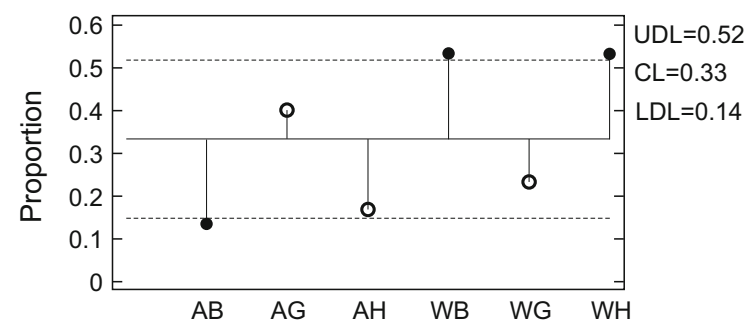

Fig. 4 The success in removal of birch recorded in 2012 expressed as a percentage of non-sprouting stumps. Winter cuts at breast height $(\mathrm{WH})$ and at the base of the trunk (WB) provided the highest proportion of non-sprouting stumps (Chi square test; $\mathrm{p}<0.05)$. $G$ cutting below the ground surface, $B$ cutting $5-10 \mathrm{~cm}$ above the ground, $H$ cutting $120 \mathrm{~cm}$ above the ground, $A$ autumn, and $W$ winter. Analysis of means with $90 \%$ decision limits. $U D L$ upper decision limit, $C L$ center line, $L D L$ lower decision limit

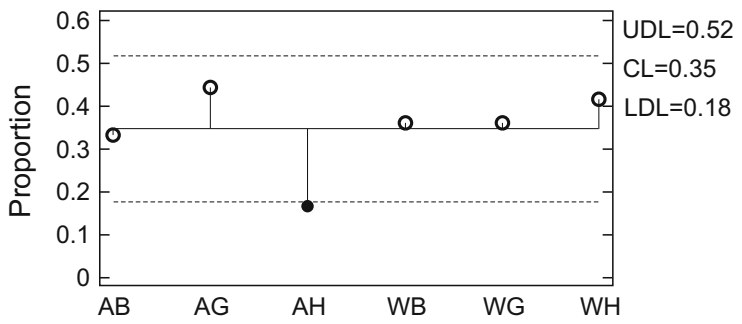

Fig. 5 The success in removal of birch recorded in 2013 expressed as a percentage of non-sprouting stumps. The most effective treatment was autumn cuts below the ground surface (AG), whereas autumn cutting (AH) was the least effective; however these differences were not significant (Chi square test) at $\mathrm{p}=0.05$. For explanations, see Fig. 4

\section{Discussion}

Betula pubescens is a biologically vigorous pioneer species that invades abandoned and unmanaged open peatlands. Therefore, its control is regarded as fundamental for the successful protection of wetland biodiversity (Faliński 1980; Smit and Olff 1998). Compared to other species, downy birch is more sensitive to cutting, while willow and poplar species can withstand numerous consecutive harvests without decrease in their sprouting capacity (Harrington and DeBell 1984; Paukkonen et al. 1992; Willebrand et al. 1993). The successful removal of invasive trees and shrubs is dependent on many factors, including the species, age of the trees, diameter of the trunk as well as timing and frequency of the cutting (Lust and Mohammady 1973; Johansson 1992b, 2008; Hytönen 1994).

In our experiment, the sprouting ability of Betula trees after the cut was highly dependent on the age of the trees, what was a rather obvious finding. Younger, thinner trees produced a smaller amount of sprouts than older individuals after the cut. A positive correlation between the stump size of Betula pendula and B. pubescens and sprouting has been observed also by Johansson (1992b). We also found that the winter cut gave more non-sprouting stumps than the cut performed in autumn. The positive effect of season of the treatment was amplified by the height of the cut. Stump height is considered as an important factor that affects the sprouting of harvested shrubs and trees. However, the literature presents different and sometimes contradictory results. In an experiment by Johansson (1986), a cut of Betula at ground level 
resulted in lower sprout production compared to cuts at $10 \mathrm{~cm}$, while Kauppi et al. (1988) reported rapid growth of birch sprouts that may catch up with the main stem cut just above the ground. Fällman et al. (2003) found that top cutting of B. pubescens at higher heights above ground level resulted in fewer forks, straighter stems, higher live crown height and smaller thickest branch diameters compared to cutting just above ground. According to Karlsson and Albrektson (2000), cutting at least $40 \%$ of the main stem height should prevent production of side/lower shoots. Our findings are to some extent consistent with the cited results. In Stare Biele, trunks cut in autumn at higher height exhibited a lower survival rate than those cut just above ground level, with the largest number of non-sprouting birch stumps (up to $50 \%$ ) yielded by a cut at breast height. Removal of downy birches seemed also be more efficient before they reached age of $\sim 15$ years. Younger trees produce a smaller number of sprouts and lighter sprouts than larger birch trees.

Surprisingly, birch appeared to be resistant to the joint interplay of mechanical and microbial interactions, and as early as spring 2013, some of the "dead" trees started to vigorously produce sprouts from the root zone. After cutting, birch produce stump sprouts primarily from dormant basal buds, and 72 to $95 \%$ of the buds appear below ground on the roots (Johansson 1992a). The "success" in eradication of Betula declined and offset to $30-40 \%$ in all the treatment plots in the second year after performing the cut (the only exception was AH). Similar results were published by Kauppi et al. (1988) and Rinne et al. (1994). In places, newly grown burgeons formed a close burst that overshaded the soil surface and threatening shadow intolerant herb layer species to a much greater extent than the original tree crown, which put the aptness of the applied treatments into question. Nevertheless, a considerable number of the living trees after cutting were infected by fungi, which suggests a progressive tree mortality in subsequent years. Trees cut above the peat surface in winter are particularly susceptible to infections by pathogens. In the treatments with cutting at the base of the trunk and at breast height in winter (treatments WB and WH), all of the stumps that had not produced sprouts and nearly $60 \%$ of the living trees were seriously infected by fungi. We noticed that the amount of living stumps attacked by fungi after cutting in autumn was only
22-25\% (generally in $\mathrm{AB}$ and $\mathrm{AH}$ plots). Cutting below the peat surface (WG and AG plots) in autumn and winter did not favor fungal infections because only single stumps (3-6\%) infected by pathogens were observed. Repeated field observations revealed that most of the stumps weakened by fungi were broken by wind and disappeared by the second year after treatment.

Betula pubescens has been shown to be unsuitable for sprouting when short rotation periods of harvesting were applied (Rydberg 2000). Hyttönen and Issakainen (2001) reported harvesting that was repeated every 1-2 years to increase the mortality of birch stumps. The second cut yielded three times less biomass than the first one, and the sprouting ability of downy birch was significantly reduced (87\% stumps failed to sprout) after just four seasons of cutting. However, in some cases, a number of birches were able to sprout for more than 10 years of management (Hyttönen and Issakainen 2001). The experiment carried out in the "Rynki" peatland located in the Narew National Park showed that $94 \%$ of the treated birch resprouted vigorously despite four successive cuts performed year by year (Kamocki, unpublished raw data). In some cases, tree growth and sprouting after the implementation of cutting management can be inhibited by such factors as frost damage in early autumn or late spring (Linkosalo et al. 2000), browsing by large herbivores (Gill 1992; Barančeková et al. 2007) or destruction by insects (Tenow et al. 2005). Nonetheless, this additional effect was not observed in the studied peatland.

\section{Conclusions}

Restoration and conservation efforts of reforested wetlands often lack experimental validation, particularly for different methods of cutting and terms of treatment. Our study showed that birch trees cut at the higher tested height exhibited a lower survival rate than those cut below or just above the ground level. Furthermore, the winter cut produced more nonsprouting stumps than those recorded after the cut performed in autumn. In our opinion, winter cutting at breast height is the best management strategy for downy birch control. We recommend the removal of downy birch trees from peatlands before they have achieved an age of 15 years. Younger trees produce a 
lower number of sprouts and lighter sprouts compared to larger birch trees.

Our results suggest that effective elimination of Betula by a single cut is rather unlikely and that control measures should be either repeated in subsequent years or boosted by additional treatments, e.g., applications of herbicide. However, the secondary impact of the control operation on the environment must be considered because there is a hazard of aquatic toxicity and bioaccumulation, especially in the case of sensitive ecosystems of high ecological value. Nevertheless, the planning of active protection measures in such habitats requires great caution because birch trees are not always invasive species within peatland communities and they may not cause a threat in specific environments.

Acknowledgements We gratefully acknowledge two anonymous reviewers for their thoughtful comments and suggestions which helped to improve our manuscript. This research was supported by Polish Ministry of Science and Higher Education (Grant N N305 3673 38).

Open Access This article is distributed under the terms of the Creative Commons Attribution 4.0 International License (http:// creativecommons.org/licenses/by/4.0/), which permits unrestricted use, distribution, and reproduction in any medium, provided you give appropriate credit to the original author(s) and the source, provide a link to the Creative Commons license, and indicate if changes were made.

\section{References}

Banaszuk P, Kamocki AK, Zarzecki R (2016) Mowing with invasive machinery can affect chemistry and trophic state of rheophilous mire. Ecol Eng 86:31-38

Barančeková M, Krojerová-Prokešová J, Homolka M (2007) Impact of deer browsing on natural and artificial regeneration in floodplain forest. Folia Zool 56:354-364

Bart D, Davenport T, Yantes A (2015) Environmental predictors of woody plant encroachment in calcareous fens are modified by biotic and abiotic land-use legacies. J Appl Ecol. doi:10.1111/1365-2664.12567

Baylis K, Peplow S, Rausser G, Simon L (2008) Agri-environmental policies in the EU and United States: a comparison. Ecol Econ 65(4):753-776

Bond WJ, Midgley JJ (2001) Ecology of sprouting in woody plants: the persistence niche. Trends Ecol Evol 16:4551

Brisson J, Cogliastro A, Robert M (2006) Controlling speckled alder (Alnus incana ssp. rugosa) invasion in a wetland reserve of southern Québec. Nat Areas J 26(1):78-83

Claassen R, Cattaneo A, Johansson R (2008) Cost-effective design of agri-environmental payment programs: U.S. experience in theory and practice. Ecol Econ 65(4):737-752

COM (2015) Report from the Commission to the Council and the European Parliament. The state of nature in the European Union. Report on the status of and trends for habitat types and species covered by the birds and habitats directives for the 2007-2012 period as required under Article 17 of the Habitats Directive and Article 12 of the Birds Directive. Available via European Commission. http://ec. europa.eu/transparency/regdoc/rep/1/2015/EN/1-2015-219EN-F1-1.PDF. Accessed 02 Dec 2015

Delvaux C (2009) "Strip-trees": the life after. Responses to bark harvesting of medicinal tree species from Forêt Classée des Monts Kouffé, Benin. Ph.D. thesis. Faculty of Bioscience Engineering, Ghent University, Belgium

EEA (2015) Technical report No 2/2015. State of nature in the EU. Results from reporting under the nature directives 20072012. ISSN 1725-2237. Available via European Environment Agency. http://www.eea.europa.eu/publications/stateof-nature-in-the-eu. Accessed 02 Dec 2015

Faliński JB (1980) Vegetation dynamics and sex structure of the populations of pioneer dioecious woody plants. Vegetatio 43:23-38

Fällman K, Ligné D, Karlsson A, Albrektson A (2003) Stem quality and height development in a Betula-dominated stand seven years after precommercial thinning at different stump heights. Scand J For Res 18(2):145-154

Ferm A, Kauppi A (1990) Coppicing as a means for increasing hardwood biomass production. Biomass 22:107-121

Gill RMA (1992) A review of damage by mammals in north temperate forests: 1. deer. Forestry 65:145-169

Grygoruk M, Batelaan O, Mirosław-Świątek D, Szatyłowicz J, Okruszko T (2014) Evapotranspiration of bush encroachments on a temperate mire meadow-A nonlinear function of landscape composition and groundwater flow. Ecol Eng 73:598-609

Harrington CA, DeBell DS (1984) Effects of irrigation, pulp mill sludge, and repeated coppicing on growth and yield of black cottonwood and red alder. Can J For Res 14:844-849

Heijmans MMPD, van der Knaap YAM, Holmgren M, Limpens J (2013) Persistent versus transient tree encroachment of temperate peat bogs: effects of climate warming and drought events. Glob Change Biol 19(7):2240-2250

Hytönen J (1994) Effect of cutting season, stump height and harvest damage on coppicing and biomass production of willow and birch. Biomass Bioenergy 6:349-357

Hyttönen J, Issakainen J (2001) Effect of repeated harvesting on biomass production and sprouting of Betula pubescens. Biomass Bioenergy 20:237-245

Jabłońska E, Falkowski T, Chormański J, Jarzombkowski F, Kłosowski S, Okruszko T, Pawlikowski P, Theuerkauf M, Wassen MJ, Kotowski W (2014) Understanding the long term ecosystem stability of a fen mire by analyzing subsurface geology, eco-hydrology and nutrient stoichiometry-Case study of the Rospuda Valley (NE Poland). Wetlands 34:815-828

Jickells T (2005) External inputs as a contributor to eutrophication problems. J Sea Res 54(1):58-69

Jobidon R (1997) Stump height effects on sprouting of mountain maple, paper birch and pin cherry-10 year results. For Chron 735:590-595 
Johansson T (1986) Development of suckers by two-year-old birch (Betula pendula Roth) at different temperatures and light intensities. Scand J For Res 1:17-26

Johansson T (1992a) Dormant buds on Betula pubescens and Betula pendula stumps under different field conditions. For Ecol Manag 47:245-259

Johansson T (1992b) Sprouting of 2- to 5-year-old birches (Betula pubescens Ehrh. and Betula pendula Roth) in relation to stump height and felling time. For Ecol Manag 53:263-281

Johansson T (2008) Sprouting ability and biomass production of downy and silver birch stumps of different diameters. Biomass Bioenergy 32:944-951

Karlsson A, Albrektson A (2000) Height development of Betula and Salix species following precommercial thinning at various stamp heights: 3-year results. Scand J For Res 15:359-367

Kauppi A, Rinne P, Ferm A (1988) Sprouting ability and significance for coppicing of dormant buds on Betula pubescens Ehrh. stumps. Scand J For Res 3:343-354

Klimkowska A, Dzierża P, Kotowski W, Brzezińska K (2010) Methods of limiting willow shrub re-growth after initial removal on fen meadows. J Nat Conserv 18:12-21

Kołos A, Banaszuk P (2013) Mowing as a tool for wet meadows restoration: effect of long-term management on species richness and composition of sedge-dominated wetland. Ecol Eng 55:23-28

Kołos A, Wołkowycki D, Banaszuk P, Kamocki AK (2015) Protection of relic plant species at the limit of geographical range: response of downy willow Salix lapponum to removing a competitor. Ann Bot Fenn 52:303-314

Kotowski W, Piórkowski H (2005) Competition and succession affecting vegetation structure in riparian environments: implication for nature management. Ecohydrol Hydrobiol 5(1):51-57

Linkosalo T, Carter TR, Häkkinen R, Hari P (2000) Predicting spring phenology and frost damage risk of Betula spp. under climatic warming: a comparison of two models. Tree Physiol 20:1175-1182

Luostarinen K, Kauppi A (2005) Effect of coppicing on the root and stump carbohydrate dynamics in birches. New For 29:289-303

Lust N, Mohammady M (1973) Regeneration of coppice. Sylva Gardavensis 39:1-28

Meli P, Rey Benayas JM, Balvanera P, Martínez Ramos M (2014) Restoration enhances wetland biodiversity and ecosystem service supply, but results are context-dependent: a meta-analysis. PLoS ONE 9(4):e93507. doi:10. 1371/journal.pone.0093507

Middleton BA, Holsten B, van Diggelen R (2006) Biodiversity management of fens and fen meadows by grazing, cutting and burning. Appl Veg Sci 9:307-316

Økland RH, Økland T, Rydgren K (2001) A Scandinavian perspective on ecological gradients in north-west European mires: reply to Wheeler and Proctor. J Ecol 89:481-486
Paukkonen K, Kauppi A, Ferm A (1992) Origin, structure and shoot-formation ability of buds in cutting-origin stools of Salix 'Aquatica'. Flora 186:53-65

Read H (2000) Veteran trees: a guide to good management. English Nature, Peterborough

Riemersma S, Little J, Ontkean G, Moskal-Hébert T (2006) Phosphorus sources and sinks in watersheds: a review. In: Alberta Soil Phosphorus Limits Project. Background information and reviews, vol 5. Alberta Agriculture, Food and Rural Development, Lethbridge, Alberta, Canada

Rinne P, Saarelainen A, Juntilla O (1994) Growth cessation and bud dormancy in relation to ABA level in seedlings and coppice shoots of Betula pubescens as affected by a short photoperiod, water stress and chilling. Physiol Plant 90:451-458

Rydberg D (2000) Initial sprouting, growth and mortality of European aspen and birch after selective coppicing in central Sweden. For Ecol Manag 130:27-35

Smit R, Olff H (1998) Woody species colonisation in relation to habitat productivity. Plant Ecol 139:203-209

Smith VH, Tilman GD, Nekola JC (1999) Eutrophication: impacts of excess nutrient inputs on freshwater, marine, and terrestrial ecosystems. Environ Pollut 100(1-3): 179-196

Sura S, Waiser M, Tumber V, Farenhorst A (2012) Effects of herbicide mixture on microbial communities in prairie wetland ecosystems: a whole wetland approach. Sci Total Environ 435-436:34-43

Tenow O, Bylund H, Nilssen AC, Karlsson PS (2005) Longterm influence of herbivores on northern birch forests. Ecol Stud 180:165-181

Tousignant ME, Pellerin S, Brisson J (2010) The relative impact of human disturbances on the vegetation of a large wetland complex. Wetlands 30:333-344

Warren RJII, Pittillo JD, Rossell IM (2004) Vascular flora of a southern Appalachian fen and floodplain complex. Castanea 69:116-124

Warren RJII, Rossell IM, Moorhead KK, Pittillo JD (2007) The influence of woody encroachment upon herbaceous vegetation in a southern Appalachian wetland complex. Am Midl Nat J 157:39-51

Willebrand E, Ledin S, Verwijst T (1993) Willow coppice systems in short rotation forestry: effects of plant spacing, rotation length and clonal composition on biomass production. Biomass Bioenergy 5:323-331

Zhu WZ, Xiang JS, Wang SG, Li MH (2012) Resprouting ability and mobile carbohydrate reserves in an oak shrubland decline with increasing elevation on the eastern edge of the Qinghai-Tibet Plateau. For Ecol Manage 278:118-126

Żurek S (2000) Stratygrafia, geneza i wiek torfowiska. In: Czerwiński A, Kołos A, Matowicka B (eds) Dynamika siedlisk i roślinności torfowisk uroczyska Stare Biele w Puszczy Knyszyńskiej. Politechnika Białostocka, Białystok, pp 40-69 